\title{
Social Networks and Innovation in Industrial Clusters: A Study in case of Turkish Industrial Clusters
}

\author{
Sanayi Kümelerinde Sosyal Ağlar ve Yenilikçilik: \\ Türk Sanayi Kümeleri Örneğinde Bir Çalışma
}

\author{
Özer KARAKAYACl, İclal DiNÇER
}

Over the last three decades, one of the most important issues in economic geography and regional development, which have occurred in the background of industrial clusters, is concerned with understanding factors such as social, economic and spatial characteristics based on social capital, social networks, trust and proximity. Increasing interest in clusters has focused on issues such as how these factors will be the role of evolution within industrial clusters. In this paper, non-economic factors behind the evolution of industrial clusters in Turkey have been discussed through social networks. The aim of this article is to determine the role of social networks on evolution of innovation in industrial clusters. In this context, the main hypothesis about the source of social networks and innovation is that social networks have a decisive influence on the changing of innovation activities through formal and informal linkages having out-cluster and intra-cluster of Ankara and Konya machinery engineering firms. The data used in the study were obtained by in-depth interviews and surveys conducted on sample clusters. It has been verified that social networks are determinants of innovation, although the social networking potentials of the clusters are different.

Keywords: Industrial clusters; product innovation; process innovation; social networks; Turkey.

Öz

Son otuz yılda endüstriyel kümelerin arka planını inceleyen ekonomik coğrafya ve bölgesel kalkınma yazınının odaklandığı konulardan biri de sosyal sermaye, sosyal ağlar, güven ve yakınlık temelli sosyal, ekonomik ve mekânsal özelliklerin anlaşılmasıyla ilgilidir. Nasıl bu faktörlerin sanayi kümelerinin gelişiminde rolü olacağı endüstriyel kümelere yönelik ekonomik coğrafya yaklaşımının temel tartışma noktasıdır. Makalede, Türkiye'de sanayi kümelerinin gelişiminin arkasında yatan ekonomik olmayan faktörler sosyal ağlar perspektifinde değerlendirilmiştir. Bu çerçevede, çalışmanın amacı sanayi kümelerinde yenilikçilik aktivitelerinin gelişiminde sosyal ağların rolünü keşfetmektir. Bu bağlamda çalışmanın ana hipotezi, sosyal ağların Ankara ve Konya makine sanayi kümelerinin küme içi ve küme dışında sahip olduğu formel ve enformel bağlantıların yenilikçi aktivitelerin gelişiminde belirleyici bir etkiye sahip olduğudur. Çalışmada kullanılan veriler, örnek kümelerde yapılan derinlemesine görüşmeler ve anket çalışmalarıyla elde edilmiştir. Çalışmada, kümelerin sahip olduğu sosyal ağ potansiyelleri her ne kadar değişiklik gösterse de, sosyal ağların yenilikçi aktivitelerin gelişiminde belirleyici olduğu doğrulanmıştır.

Anahtar sözcükler: Sanayi kümeleri; ürün yenilikçiliği; süreç yenilikçiliği; sosyal ağlar; Türkiye.

'Department of City and Regional Planning, Selçuk University Architecture Faculty, Konya, Turkey ${ }^{2}$ Department of City and Regional Planning, Yıldız Technical University Architecture Faculty, İstanbul, Turkey

Article arrival date: August 27, 2017 - Accepted for publication: April 11, 2018

Correspondence: Ozer KARAKAYACI. e-mail: karakayaci@gmail.com

๑ 2018 Yıldız Teknik Üniversitesi Mimarlık Fakültesi - ๑ 2018 Yıldız Technical University, Faculty of Architecture 


\section{Introduction}

Since the 1990s, industrial geography has focused on the role in regional economic development of 'industrial districts or 'industrial clusters'. This structure brings network-oriented discussions in its wake. It is important to discuss the role of networks among the supporting institutions and their characteristics, which rely on the evolution stories of industrial clusters, since they have reflected the value of social and cultural factors in industrial clusters. In this context, social networks are the focus of attention of diverse disciplines such as sociology, economic and politic geography, and regional development. Social network (SNs) emphasize on the importance of the relationships among all of the actors in a particular environment, as a criticism to the neoclassical approach, which explains the abstract of spatial and social factors from economic landscape. It causes SNs have a key role for knowledge and learning processes in industrial clusters. SNs, therefore, have been extensively discussed in the evolution of industrial clusters as an engine of regional development in the literature.

Characteristics of clusters, however, have an indirect effect on how SNs have formed in terms of both the power and content of the relations. The power in SNs is expressed as spending time, ideas, and advice while the content is evaluated in a frame of concepts such as knowledge sharing, learning and innovation (Agapitova, 2003; Castilla, Hwang, Granovetter \& Granovetter, 2000). Therefore, characteristics of clusters play an important role in the increase of power and in the diversification of content in the channels while SNs form new knowledge channels by means of informal and formal ways of presenting various information sources. In short, the strong SNs paves the way for creativity and innovation processes with the diffusion of new knowledge (Hauser, Tappeiner, \& Walde, 2007).

In this article, we consider innovative activities of firms in the evolution of clusters and different relation types among all actors within SNs in different geographic level. Within this framework, the article consists of five main parts. The first part gives a conceptual framework of the study. The second part consists of a theoretical background such as industrial clusters, innovation, and SNs. The third discusses about the method and hypothesis of the study. It then follows on to the fourth part that explains the result of the analysis concerned with research findings. The fifth is discussion section and final part is conclusions and suggestions that have been gained from the research. The overall aim of the article is to prove the role of SNs on the success of clusters in the case of Ankara and Konya mechanical engineering clusters (MEC), which have different characteristics of social, institutional and economic features in terms of production organisations.

\section{Theoretical Backgrounds: Industrial Clusters, Social Networks and Innovativeness}

\section{Industrial Clusters and Social Networks}

Industrial clusters express that clusters not only are not composed of territorial agglomeration, but are also regions where innovation, sharing knowledge, R\&D, education activities take place with both spatial features and socio-cultural structure. Industrial clusters deal with a wide range of social issues including untraded interdependencies or relational assets, mutual relations, habits, norms and trust as well as territorial agglomeration (Amin \& Thrift, 1994; Storper, 1999). Thus, due to potential social integration regarded as institutional thickness, untraded interdependencies, common cultural structure, sharing knowledge, innovation for economic and social benefits of networks (Eraydin \& Armatli-Koroglu, 2005), industrial clusters may show different spatial networks. In perspective, Gordon and McCann (2000) argue that industrial cluster could classify territorial agglomeration, industrial complex and SNs. However, it is important to recognise that SNs are too complicated to express different concepts such as clusters, innovation, trust and social capital, face to face relations while territorial agglomeration and industrial complex are to represent one-dimension as spatial proximity and architectural structure.

The most important studies for SNs in economic and industrial geography was made by Granovetter (1973) who placed SNs in disparity structures (strong ties and weak ties). Granovetter argues on how the strength of weak ties contributes to the development of success for actors. He claimed that strong ties bring forth normative networks such as family, friends and acquaintances based on sociocultural background. In the framework perspective, this can be seen as a bridge for the diffusion of knowledge between normative networks; however, this may result in the inhibition of the changing of the actors from certain rounds of circulation, which will create knowledge or learning milieu from normative relation. Granovetter, also, defends weak ties that can effectively access new research and the values shared by the majority for providing information from varied networks (Lin, 2001). The assumption on the power of weak ties is frequently cited in the literature as evidence of the role of clusters in economic development. This is also supported by Burt's "structural holes" approach, which has similar characteristics with the hypothesis "strength of weak ties" (2004). According to Burt, actors that provide a connection or contact among varied information sources can be a significant point for new knowledge channels and different ways of thinking and creativity.

However, there are studies revealed that weak ties do not always have a positive effect on the success of knowl- 
edge channels. In Chen's study of the Taiwan bicycle industry cluster (Chen, 2002), he argues that knowledge acquired through $R \& D$ and trial or experiences is more significant than knowledge obtained by SNs. (Aloysius Gunadi, 2011) also states that SNs have a limited effect on innovative processes, since different indicators should be used to detect the role of SNs in innovation of clusters.

Within the light of the above debates, there are numerous discussions about whether SNs have a positive effect on the evolution of clusters or innovation. The reason that evidences can vary immensely from each other is due to the methodological approaches that are taken in the discussion. This is due to the fact that SNs are a system, which have various characteristics such as relational, temporal and spatial dimensions. This complex system can lead to the emergence of different results in empirical studies. Relational dimensions of SNs, for example, can refer to a lot of factors to quality and diversity of relations for understanding the attitude and values of networks (trust, social capital, close friends) from the quantity of relations for understanding the route and density of networks (nodes, bridges). Trust and social capital is defined as an important concept for both acquiring new knowledge channels and removing the negative effects of networks in the learning and innovation process in industrial geography (Malecki \& Tootle, 1996; Uzzi, 1997). In addition, nodes and bridges in the closed social circle can lead a trigger by the production process based on imitation and locked-in innovation processes. Temporal dimension points to the interaction processes of SNs that is a dynamic process in the context of time, such as student-teacher relations etc. Student-teacher relations, for example, only takes place in school periods and expires once the bell rings. Knowledge spillovers cannot trigger innovative activities due to knowledge sharing not occurring in clusters if these interactions do not set channels of communications by SNs in a particular time. Spatial dimensions refer to face-to-face relations and mobility of actors permitted by spatial proximity SNs (Staber, 2001). However, it is argued whether spatial proximity is the necessary arrangement for enhancing SNs, which fosters the growth of innovation and learning activities, since social capital and trust may have an impact that reduces the importance of spatial proximity. Even so, spatial proximity can still be accepted as an important factor for continuity of trust and encouraging face-to-face relations since coordination, cooperation and innovation, learning, and sharing is increased by SNs supported trust and face-to-face interactions as a 'social glue' (Staber, 2001).

To summarize the theoretical context, SNs may make a positive contribution to innovation and learning of industrial clusters. Due to the varied approaches in SNs, it may lead significantly diverse findings in empirical studies. The complex structure of SNs can be identified as 'dark holes' by literature (Staber, 2007). Thus, data structures and variables (obtained through how, which, when) referring to dimensions of SNs are the main reason of the ambiguity in empirical studies on innovation of SNs in clusters. However, methodological issues focusing on statistical analysis give rise to discussions of findings in SNs especially those that are defined by abstract component as trust, confidence culture and close friends. Statistical evidences do not adequately express relations carrying out in social milieu due to the static structure of statistical analysis. In this literature, it is stated that this issue may be minimised through interpretations of statistical results, with findings obtained by in-depth analysis.

\section{Innovation}

Innovation is a learning process consisting of the development of product, mutual relationships, improvement of social habits and organizations, as well as the production of new products for sectors and a transition to new process for firms (Armatli-Koroglu, 2005; Morgan, 1997). It has begun to be regarded as an important process, shaping a complex structure from production and marketing models to organisation models, from new marking and competitive conditions to specialization and division of labour. This perspective has forced actors to find a way to encourage the development of competitive conditions of firms and nation-states: intangible components (as sharing, mobility, cooperation-coordination, mutual agreement, habit, social interaction and social capital) as well as tangible components (as technical suggestions, physical and financial arrangements) (Landry, Amara, \& Lamari, 2002). On the one hand, these components, especially sharing, mobility, cooperation-coordination, mutual agreement, habit, social interaction and social capital, find new channels to combine knowledge resources (Kogut \& Zander, 1992). On the other hand, knowledge resources such as competitive firms, universities, research institutions, technology centres and particularly customers providing significant contribution to innovation with claims and ideas have provided inspiration for innovative activities (Todtling \& Kaufmann, 2001). Innovation, thus, not only is an issue to be explained by tangible components such as R\&D, technical and physical arrangements, but also has begun to become a strategic issue based on the ability to cooperate with other actors and institutions over the last three decades for the success of economic actors.

Innovative activities referring to new channels for external knowledge resources, pave the way for adapting to the changing conditions of actors with intangible components. However, there are broad consensuses about whether the innovative activities called interaction-learning process 
have a key role in the success or evolution of clusters or firms (Romijn \& Albaladejo, 2002). Knack and Keefer (1997) emphasize on innovation of trust developed through interaction. They argue that high-trust among actors lead to declination of both high uncertainty-risk for learning and spending more time for innovative activities because of reducing transaction cost such as tax, bribes, service and contracts fee etc. Furthermore, Molina-Morales and Martínez Fernández (2010) have a general idea to enhance innovative activities by SNs being cautious about giving information. This is generally discussed to explain the effect on innovation or firms' development with interrelated concepts in the literature: institutional thickness (Amin and Thrift, 1994), untraded interdependencies (Storper, 1999), cultural environment (Gertler, 1997; Maskell \& Malmberg, 1999; Saxenian, 1994), SNs and social capital (Cooke, Clifton, \& Oleaga, 2005; Dicken \& Malmberg, 2001; Grabher, 1993; Martin \& Sunley, 2001) as regards evolutionary and relational economic geography.

In this process, it is essential to have new information for locating at a particular position of an actor in interaction learning. Namely, if actors would like to be a part of the process of obtaining knowledge within SNs, they must have potential knowledge resources or have the capacity to process external knowledge into its own production for innovative activities. Thus, addition to external knowledge, internal sources that are considered an important part in innovative activities due to physical potential of actors (tangible components). Although this has a traditional perspective about innovation, there is a consensus that learning capacities can be enhanced by attributes such as R\&D intensity, entrepreneur experience, size and types of workforce (Johansson \& Lööf, 2008; Romijn \& Albaladejo, 2002). This is because 'learning by doing', which is the traditional learning process can be achieved only through internal factors (Romijn \& Albaladejo, 2002).

Accordingly, with the aid of internal sources of codified information acquiring from external sources through intangible components such as SNs, trust, social capital, habit, this supports that innovation expresses an interactive and path-dependence process providing the value to the production process such as technological structure to employment structure, marketing strategies to institutional strategies, physical facilities to machine potentials etc..

Innovation is to point out a complex structure as a result of being a comprehensive description of this production process in clusters. There are discussions on disparity definitions of innovation for analysis of the complex structure in which they generally focus on two dimensions as product and process innovation (Aloysius Gunadi, 2011). Besides the introduction of new products or technologies and adapting of new processes for manufacturing, product innovation may be described as significant qualitative improvements in existing products and institutional structures (Freel, 2000; Romijn \& Albaladejo, 2002). Product innovation should be a newly developed product or production technologies and let institutional and organizational restructure into competitive firms or markets (Freel, 2000). If the newly developed product is new for a firm and not new for a market, the degree of innovation is evaluated as nominal (Karlsson, 1997; Todtling \& Kaufmann, 2001). Product innovation also means to promote new products in the market because of the essential improving, renewal and technologic developments in existing products. The customers, suppliers, institutions and associated organisations, thus, are the main sources of both new ideas and opinions for product innovation and development of long-term strategies for firms. In other words, product innovation occurs to both fulfil the consumer's expectations and demands, and determine long-term strategies of firms (Todtling \& Kaufmann, 2001). Because of this features of product innovation, this is not only for high-tech sectors such as machine, automotive, electronics etc. but also for textile, footwear etc.

Process innovation should be described as a process, which is completely independent from product innovation. This innovation was accepted as a regulation process rather than a complete renewal of the manufacturing process, or providing flexible conditions, or adaptation process to production technique used for obtaining new or developed product or new technologies. This covers all regulations and improvements in the manufacturing process, marketing and supplier (Todtling \& Kaufmann, 2001). Also, it is not limited to changes made in manufacturing and can be identified as a radical change through reviewing, configuring, improvement, and development of all processes (Romijn \& Albaladejo, 2002). This may also play a role in survival or competition of small firms with the help of sharing the knowledge developed by other firms. Process innovation, thus, is to be evaluated as strategies reducing the risk and the survival (Romijn \& Albaladejo, 2002; Sverrisson, 1994) and process determining the short-term politics in the crisis period, especially small firms.

Consequently, theoretical contributions argue that innovation, especially for industrial clusters, has introduced a new approach with changing conceptual perspectives over the last three decades. As mentioned above, there are noneconomic factors such as intangible components on the foundation of this changing structure. The Intangible components can let actors take knowledge from other firms or institutions. This brings about the degree and types of innovation depending on which channels, which time period, how interactions to this knowledge are acquired. 


\section{Methodology}

The main problem of this article is whether SNs have an effect on the product and process innovation of mechanical engineering manufacturing firms in Turkey. This article aims to explore the role of SNs on innovation in two high-tech industrial clusters of Turkey: Ankara and Konya mechanical engineering clusters (MEC), since these clusters have been based on differentials of manufacturing organisation to institutional structure and socio-cultural features.

Ankara is the most important metropolitan area after Istanbul metropolitan city. Although mostly specializing in domestic and foreign services, and education since the 1920s, Ankara has significantly positioned into manufacturing sectors within Turkey's industrial geography. Over the last six decades, Ankara has especially concentrated on machinery, defence industry, electronics and software. These sectors have a highly competitive role since they are located near to institutions such as universities, public and private organizations, R\&D centres, and technology parks. Especially in Ankara where there are tenders such as largescale individual projects and national defence projects, the firms want to be near them to have a strong relationship with public enterprises. This situation has affected the supplier and subcontracting firms to cluster around the firms. Besides, a wide knowledge and experience gained within last 60 years have brought on the integrated firms to the production chain in global level. Konya is known as an agricultural province in Turkey. The importance of the manu- facturing industry in Konya dates back to the foundation of the republic (1923). It has converted to agricultural machinery production via experiencing obtained by agricultural production carrying out mechanisation in the 1950s. The machine manufacturing which was developed by the effect of the agricultural production caused the habits of agricultural production to reflect on the machine-manufacturing period. Konya MEC has produced more than half of Turkey's agricultural machineries and manufacturing equipment. Konya has continued to convert to industrial machine production and automotive production in parallel to the declining agricultural machinery productions since 2000s.

The aim of this article is to determine what types of SNs have a more significant effect on innovation. To conceptualize SNs and innovation, as mentioned in the theoretical parts, this article would use the different dimensions of SNs (informal, formal and institutional linkages) and innovation variables (product and process innovation) (Figure 1). Also, it is expressed the effects of internal information sources (IIS) on innovation in Figure 1. This article has determined the hypotheses for defining the relations among the variables in two clusters in case of Turkey.

Informal linkages refer to strong ties hypothesized by Granovetter. He claims that strong ties combine with normative relations such as family, friends and acquaintances. Informal linkages, in other words, have not been sufficient sources for radical changes and competition based on innovation, for circulations of knowledge in similar groups,

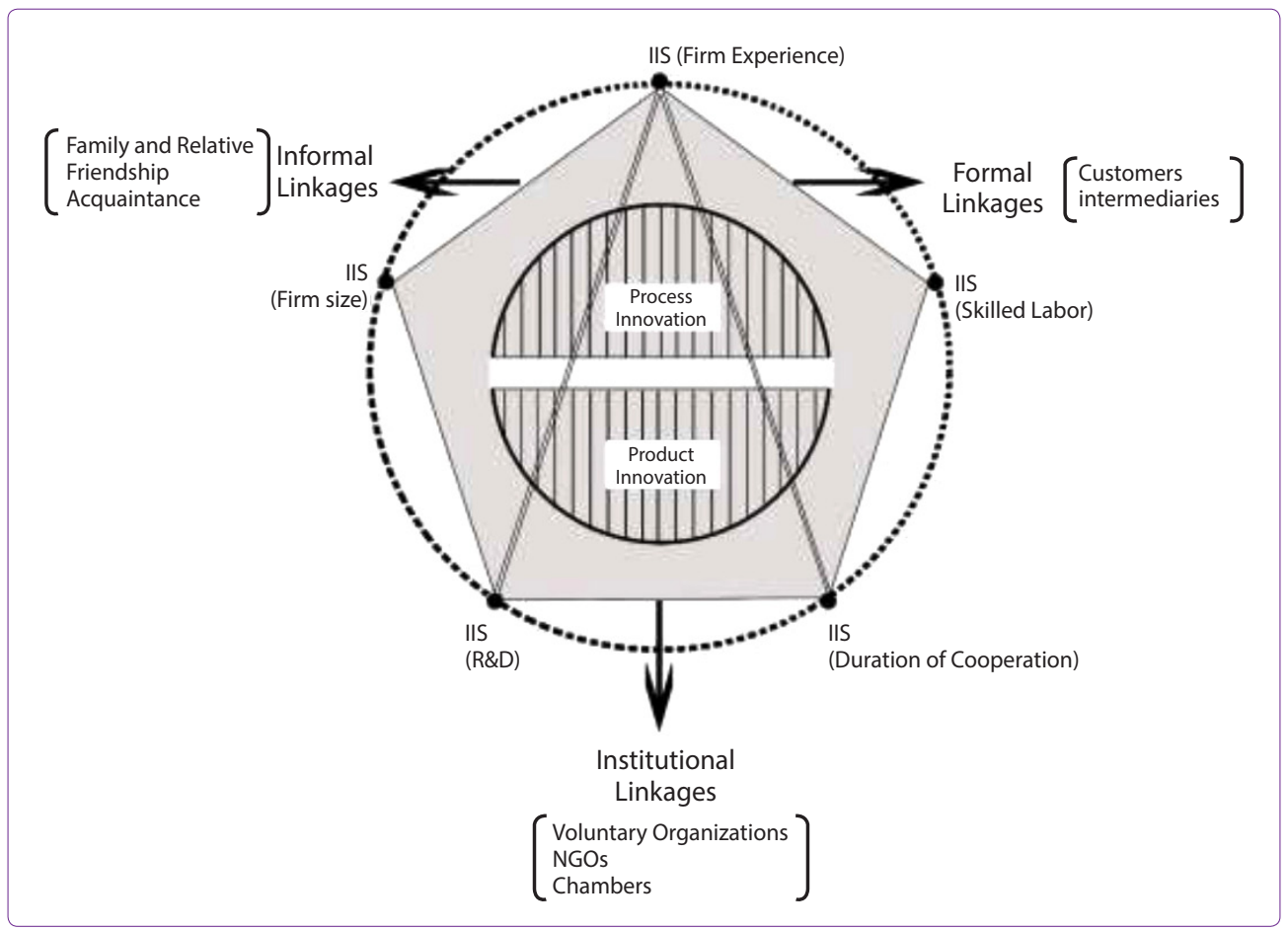

Figure 1. Social networks, innovation and internal information sources in clusters. 
Table 1. Number of the samples according to size in Ankara and Konya, 2010

\begin{tabular}{|c|c|c|c|c|}
\hline & Micro Firms & Meso Firms & Macro Firms & Total \\
\hline \multicolumn{5}{|l|}{ ANKARA } \\
\hline The Number of Manufacturing Firms & 15397 & 2423 & 854 & 18674 \\
\hline Mechanical Engineering Manufacturing Firms & 735 & 56 & 14 & 805 \\
\hline The Number of Surveys & 52 & 16 & 3 & 81 \\
\hline Standard Deviation & 7.17 & 24.57 & 87.18 & ---- \\
\hline Maximum & 49 & 244 & 1590 & 1590 \\
\hline Minimum & 1 & 50 & 264 & 1 \\
\hline KONYA & Micro Firms & Meso Firms & Macro Firms & Total \\
\hline The Number of Manufacturing Firms & 8073 & 982 & 220 & 9275 \\
\hline Mechanical Engineering Manufacturing Firms & 503 & 27 & 2 & 532 \\
\hline The Number of Surveys & 72 & 16 & 1 & 89 \\
\hline Standard Deviation & 9.34 & 46.94 & 15.56 & ---- \\
\hline Maximum & 48 & 208 & 275 & 275 \\
\hline Minimum & 1 & 50 & 253 & 1 \\
\hline
\end{tabular}

which has centred on these actors (Fukuyama, 1995; Lissoni, 2001). Granovetter, who conceptualised the strength of weak ties, focused on their number and quality by giving access to different knowledge resources among firms and institutions in different levels. However, this is significant in order to sustain the competitive advantages of firms, since weak ties enable more effective access to new resources than values shared by the majority (Hauser et al., 2007; Lin, 2001). Within the context of this article, weak ties will be referred to formal and institutional linkages. Accordingly, the relations between SNs and innovation can be hypothesized as follows;

$1^{\text {st }}$ Hypothesis: The higher the significance level of the informal linkages of firms the process innovation of firms will be higher than firms with formal and institutional linkages.

$2^{\text {nd }}$ Hypothesis: The higher the significance level of the formal and institutional linkages of firms, the product innovation of firms will be higher than firms with informal linkages.

This article argues also how innovative activities will be affected by internal sources of knowledge shared through SNs. Namely, it will explore the role of the interaction between internal sources and social network in innovative activities. For example, IIS such as employees, mobility job, colleagues and classmates are not only components for innovative or learning climate within firms, but they also play the role of converting innovative activities of external knowledge (Dahl \& Pedersen, 2005; Lissoni, 2001). There is also a growing awareness about the influences of firm size on innovation. It argues that big firms, both the number of employees and the size of market and profit, are more advantageous than small firms, since they can easily use the knowledge from external networks for in- novative activities due to the number of engineering, R\&D facilities and experiences (Boschma \& Ter Wal, 2007). The role of internal sources in the effects on innovation of SNs, thus, can be hypothesised as follows;

$3^{\text {rd }}$ Hypothesis: The higher the potentials of the IIS of firms such as experience, skilled labour, size, duration of cooperation, and $R \& D$, product and process innovation of firms will be higher, for they have the ability to easily integrate the tacit and codified knowledge obtained through SNs.

The sample firms for the empirical study were selected by stratified sampling to represent different sized firms in the clusters since the database of Ankara and Konya Chambers of Commerce only provide information about the numbers of employees. The firms were classified by three categories: micro, meso and macro $^{1}$ (Table 1). The data were collected by face-to-face survey and in-depth interview with randomly selected firms.

In this article, the data was classified into three groups: innovation (dependent variables), SNs (independent variables) and IIS (control variables) (Table 2). Innovation was divided into two categories: product and process innovation. SNs were based on the following variables: informal, formal and institutional linkages. IIS refer to the firm's experience, skill labour, and size (income size), duration of cooperation and percentage of R\&D expenditure within the total income of the firms.

Product innovation is the number of activities such as development of new products and manufacturing technologies, patents and utility models and process innova-

\footnotetext{
Firms are divided into three layers. Therefore, firms with 1-49 employees are determined as micro scale firms, firms with 50-249 employees are determined as meso scale firms, and firms with 250 and over employees are determined as macro scale firms.
} 
Table 2. Component, codes and types of the variables

\begin{tabular}{|c|c|c|c|c|c|}
\hline & Components & Variables & & Codes & $\begin{array}{l}\text { Methods } \\
\text { Obtaining } \\
\text { Data }\end{array}$ \\
\hline \multirow{2}{*}{ 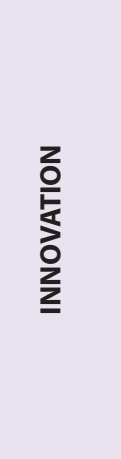 } & $\begin{array}{l}\text { The Number of Activities for } \\
\text { Development of The New Product } \\
\text { The Number of Activities for } \\
\text { Development of Manufacturing } \\
\text { Technologies and Process } \\
\text { The Number of Patents and Utility } \\
\text { Models }\end{array}$ & $\begin{array}{l}\text { PRODUCT } \\
\text { INNOVATION }\end{array}$ & $\begin{array}{l}\text { Product } \\
\text { Innovation }\end{array}$ & PRODUCT & $\begin{array}{l}\text { Dummy } \\
\text { (innovation firm 1, } \\
\text { non-innovatio } \\
\text { firm 0) }\end{array}$ \\
\hline & $\begin{array}{l}\text { The Number of Activities for } \\
\text { Improving Manufacturing } \\
\text { Technologies } \\
\text { The Number of Activities for } \\
\text { Improving Manufacturing Process }\end{array}$ & $\begin{array}{l}\text { PROCESS } \\
\text { INNOVATION }\end{array}$ & $\begin{array}{l}\text { Process } \\
\text { Innovation }\end{array}$ & PROCESS & $\begin{array}{l}\text { Dummy } \\
\text { (innovation firm 1, } \\
\text { non-innovation } \\
\text { firm 0) }\end{array}$ \\
\hline \multirow{3}{*}{ 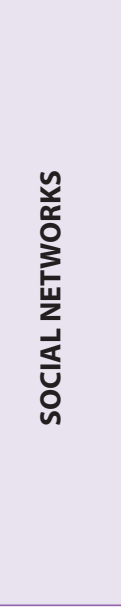 } & $\begin{array}{l}\text { The Importance of Contact with } \\
\text { Family and Relative } \\
\text { The Importance of Contact with } \\
\text { Friendship } \\
\text { The Importance of Contact with } \\
\text { Acquaintance }\end{array}$ & $\begin{array}{l}\text { INFORMAL } \\
\text { LINKAGES }\end{array}$ & $\begin{array}{l}\text { Family and } \\
\text { Relative } \\
\text { Friendship } \\
\text { Acquaintance }\end{array}$ & $\begin{array}{l}\text { FAMILY } \\
\text { FRIEND } \\
\text { ACQUAINTANCE }\end{array}$ & $\begin{array}{l}\text { Likert Scale Value } \\
\text { Likert Scale Value } \\
\text { Likert Scale Value }\end{array}$ \\
\hline & $\begin{array}{l}\text { The Importance of Contact with } \\
\text { Former Customers } \\
\text { The Importance of Contact with } \\
\text { Intermediary }\end{array}$ & $\begin{array}{l}\text { FORMAL } \\
\text { LINKAGES }\end{array}$ & $\begin{array}{l}\text { Customers } \\
\text { Intermediaries }\end{array}$ & $\begin{array}{l}\text { CUSTOMERS } \\
\text { INTERMEDIARY }\end{array}$ & $\begin{array}{l}\text { Likert Scale Value } \\
\text { Likert Scale Value }\end{array}$ \\
\hline & $\begin{array}{l}\text { The Importance of Contact with } \\
\text { Voluntary Organizations } \\
\text { The Importance of Contact with } \\
\text { Non-Government Organizations } \\
\text { The Importance of Contact with } \\
\text { Chambers }\end{array}$ & $\begin{array}{l}\text { INSTITUTIONAL } \\
\text { LINKAGES }\end{array}$ & $\begin{array}{l}\text { Voluntary } \\
\text { Organizations } \\
\text { NGOs } \\
\text { Chambers }\end{array}$ & $\begin{array}{l}\text { VOLUNORG } \\
\text { NGO } \\
\text { CHAMBER }\end{array}$ & $\begin{array}{l}\text { Likert Scale Value } \\
\text { Likert Scale Value } \\
\text { Likert Scale Value }\end{array}$ \\
\hline \multirow{5}{*}{ 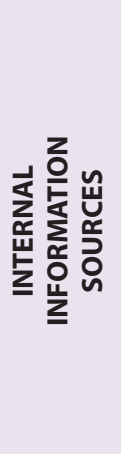 } & $\begin{array}{l}\text { Experience of Entrepreneur in } \\
\text { Firm }\end{array}$ & EXPERIENCE & $\begin{array}{l}\text { Firm' } \\
\text { Experience }\end{array}$ & EXPERINCE & Year \\
\hline & $\begin{array}{l}\text { The Number of Skilled Labour in } \\
\text { Firm }\end{array}$ & $\begin{array}{l}\text { SKILLED } \\
\text { LABOUR }\end{array}$ & Skilled Labour & SKILLAB & Number \\
\hline & $\begin{array}{l}\text { Size According to Total Income of } \\
\text { Firm }\end{array}$ & SIZE & Firm’Size & SIZE & $\begin{array}{l}\text { Categorical } \\
\text { Classification }^{1}\end{array}$ \\
\hline & Duration of Cooperation & $\begin{array}{l}\text { DURATION OF } \\
\text { COOPERATION }\end{array}$ & $\begin{array}{l}\text { Duration of } \\
\text { Cooperation }\end{array}$ & DURATION & $\begin{array}{l}\text { Dummy } \\
\text { (Short-Term: 0, } \\
\text { Long-Term: } 1 \text { ) }\end{array}$ \\
\hline & $\begin{array}{l}\text { Share Allocated by Total Income for } \\
R \& D\end{array}$ & $\begin{array}{l}\mathrm{R} \& \mathrm{D} \\
\text { EXPENDITURES }\end{array}$ & $R \& D$ & $R \& D$ & Percent Value \\
\hline
\end{tabular}

${ }^{1} . . . .<1<0.5$ Mil. $\$, 0.5$ Mil. $\$<2<1$ Mil. \$, 1 Mil. $\$<3<2$ Mil. \$, 2 Mil. $\$<4<5$ Mil. \$, 5 Mil. $\$<5<10$ Mil. \$, 10 Mil. $\$<6<25$ Mil. $\$, 25$ Mil. $\$<7<100$ Mil. $\$, 100$ Mil. $\$<8<\ldots$

tions referred to the number of activities that are aimed at improving manufacturing technologies and process by the firm. If a firm implemented at least one activity about a product or process over the last three years, it will be recognized as an innovative firm (Table 2). SNs was examined in three categories; informal linkages, formal linkages and institutional linkages. Informal linkages cover all aspects of the relations such as family and relatives, friendship and acquainted relations. Formal linkages consist of all relationships with actors being directly manufacturing as customers and intermediaries, while institutional linkages focus on interactions with institutions such as voluntary organisations, non-government organisations and chambers (Table 2). These variables were measured by five-point Likert items (Unimportant, less important, moderately important, important, very important) in the survey (Table 2). Internal information resources consist of the variables such as experience, skilled labour, size and $R \& D$ of firms. In this article, duration of cooperation was also accepted as another control variable. If the interaction is 
1 year or longer, it is defined as a long-term cooperation, and interaction less than 1 year is defined as a short-term cooperation (Table 2).

The hypotheses have been tested by statistical analysis (logistic regression) and descriptive methods (in-depth interviews and graphic display). We aimed to use a method, which focuses on interpreting in-depth interviews and graphic display, to avoid discussions over static findings obtained by our statistical analysis. This article, thus, is prepared graphics basing on average Likert values for understanding the difference between the evolution on innovation of the variables: $x y$ chart for understanding the relations between social network and innovation, and xyz chart for analysing the relations between social network, IIS and innovation. The first chart defined the average curve according to the place of the values in horizontal and vertical axis of each firm. SNs are calculated in five levels (from 1 to 5): Unimportant, less important, moderately important, important, very important (with 1 being unimportant, and 5 being very important). The values of control variables were added as presented in Table 2 in the second chart.

The in-depth interviews focus on firms' story on interactions among firms, customers, institutions and other actors for learning and innovation process. In addition, in-depth interviews consist of informal information acquired from debates about general issues after completing interviews and observation in the manufacturing areas, and conversations with employees in socio-cultural areas. Hence, the hypotheses have been comparatively tested by findings from statistical and in-depth interviews.

\section{Results of the Statistical Analysis}

SNs are evaluated by the most important components of innovation in economic and industrial geography and there are similar findings in many studies about the role of SNs on innovation. Findings were obtained by statistical analyses in two stages: possible effects of SNs and IIS on product and process innovation. In each statistical analysis, there are three models for discussion in the three components, which are informal linkages, formal linkages, and institutional linkages of SNs as dependent variable.

\section{Possible Effects of Social Networks and Internal}

\section{Information Sources on Product Innovation}

Logistic regression in the three models were analysed to estimate the possible effects of SNs on product innovation. As reported in Table 3, the coefficient of logistic regression analysis in all three models is statistically significant (model 1,2 and 3 Nagelkerke $R^{2}$ values in Ankara are respectively .658, .559, .644 and model 1,2 and 3 Nagelkerke $R^{2}$ values in Konya are respectively .458, .503, .499). In other words, all statistical analyses describe the dependent variables of independent variables that over 45 percent.
As expected, although SNs may be stated to have a significant effect on product innovation in Ankara and Konya machinery engineering industry cluster, the statistical results show that some components of social network do not have the effect on product innovation. 'Acquaintance', for example, does not have any effects on product innovation for both district firms, and 'Intermediaries' do not have effects on product innovation for firms in Ankara. As this is also related with socio-cultural backgrounds and behaviours of firms, there are statistically different findings that present results on which direction affects the components of SNs on product innovation. Also, with regards to 'Family' and 'Friendship' for firms in Ankara, the regression coefficients are negative values. The independent variables have an impact on reducing the dependent variables. In other hands, a one-unit increase in 'Family' will decrease about 2.160 (1/0.463) times and a one-unit increase in 'Friendship' leads to a decrease of $2.425(1 / 0.414)$ times in product innovation. However, compared to firms in Ankara, 'Family' and 'Friendship' for firms in Konya are the important variables for increasing product innovation. Even though theoretical discussions express that firms with less-innovation have a higher tendency of using informal linkages than formal and institutional linkages (Greene \& Brown, 1997), the statistical findings show that informal linkages maintain great importance for low and high product innovation to both districts firms, for firms in especially Konya. In other words, the dominant character of firms in Ankara and Konya reveals to the importance of informal linkages in the innovation activities. In the following, it is revealed in the finding of depth-interviews that especially the small firms consider the cooperation less risk with the actors have similar socio-cultural structure. Therefore, contrary to the theoretical approach, it could be a critical evaluation emphasizing the effect of informal linkages on the cluster success in Turkey.

The effects of formal linkages on product innovation were analysed in model 2 . As reported in Table 3 , there is a positive relationship between 'Customers' and product innovation for both district firms as it is likely to increase 1.367 times in Ankara and 1.540 times in Konya in relation to product innovation when the relationships with 'Customers' increase by one-unit. This article also determined that 'Intermediaries' have an important role on product innovation for firms in Konya, with a score of 1.755.

As reported in Table 3 (model 3), the effects of institutional linkages such as 'NGOs', 'Voluntary Organizations' and 'Chambers' on product innovation were also analysed. Institutional linkages, established through cooperation among economic and non-economic actors, play an important role in the absorption of information obtained 


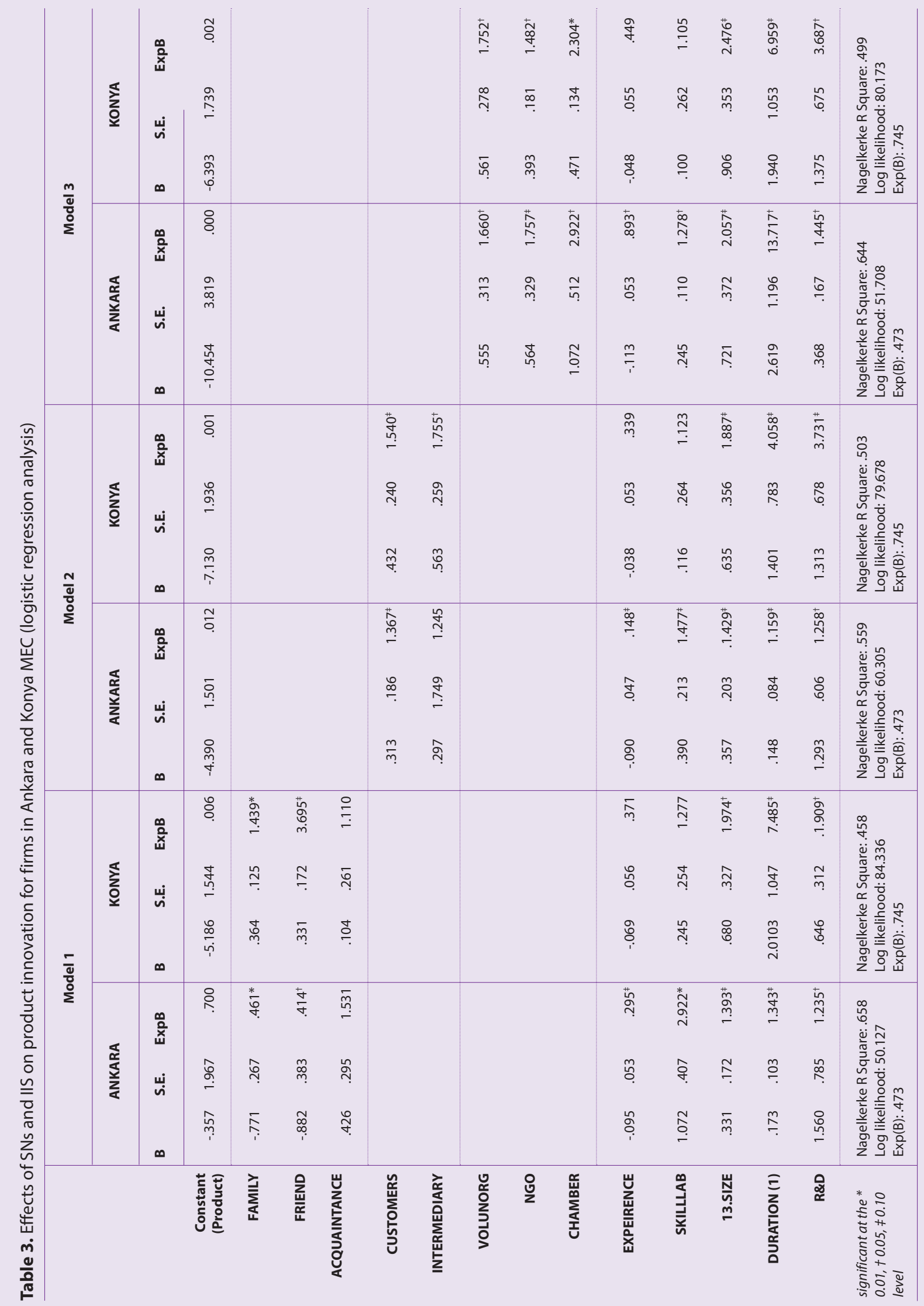


from different levels and territories in the clusters (Field, 2003; Sabatini, 2009). Accordingly, there is an important and positive relationship between product innovation and institutional linkages for firms in Ankara and Konya machinery engineering industry clusters. It should be emphasized that effects of 'Chambers' on product innovation are at a higher level than 'NGOs' and 'Voluntary Organizations' in both cases. A one-unit increase of 'Chambers', for example, will lead to more than twice of the increase for firms in Ankara and Konya in product innovation.

In addition to the explanatory variables, the effects of control variables on product innovation were analysed in the three models. This article found that this had an important effect of 'Size', 'Duration of Cooperation' and 'R\&D' on product innovation for firms in the Konya and Ankara MEC. However, there is a no significant effect on the relationship of 'Experience' and 'Skilled Labour' in all of the models in Konya. Yet, the variables in all models of Ankara, as expected, is associated with product innovation since a firm's experience is one of the factors that affect the firm's learning ability. However, this relation is an inverse relationship between 'Experience' and product innovation in Ankara since it is known that the new established firms have significantly higher learning skills due to high education level of entrepreneurs in Ankara. As can be seen in Ankara, also the higher mobility of newly established firms can also facilitate access to knowledge and learning processes (Autio, Sapienza, \& Almeida, 2000). The effects of 'Skilled Labour' on product innovation are positive in Ankara MEC. It was shown that one-unit growth of 'Skilled Labour' increases 2.922 times in model 1, 1.477 times in model 2, and 1.278 times in model 3 with respect to product innovation.

'Duration of Cooperation' was also examined within the effects on this product innovation. There is a positive and significant effect of 'Duration of Cooperation' on product innovation in Ankara and Konya MEC. In all the models, including the control variable, 'Duration of Cooperation' is the most important variable that increases product innovation because long-term cooperation, for examples, increases 13.717 times in Ankara and 6.959 times in Konya in model 3 to product innovation, and model 1 and 2 have similar situations. Consequently, all control variables, except for 'Firm' Experience' and 'Skilled Labour' in Konya, are associated with product innovation for firms in Ankara and Konya.

\section{Possible Effects of Social Networks and Internal Information Sources on Process Innovation}

The possible effects of SNs on process innovation were analysed in three different models. As reported in Table 4 , the coefficient of logistic regression analysis in all three models is statistically significant (model 4, 5 and 6 Nagelkerke $R^{2}$ values in Ankara are respectively .529, .478, .494 and 4,5 , and 6 Nagelkerke $R^{2}$ values in Konya are respectively .804, .825, .815). In other words, all statistical analyses describe the dependent variables of independent variables that are over 47 percent insomuch that Nagelkerke $R^{2}$ values in Konya is over 80 percent.

The empirical results indicate that SNs are significantly important in Konya than they are in Ankara since there are only relationships between 'Family', 'Friendship' and process innovation for firms in Ankara. The other components of SNs do not have the effects on process innovation for Ankara firms. In other words, neither 'Acquaintance' as informal linkages and 'Customers' and 'Intermediaries' as formal linkages, nor 'Voluntary Organizations', 'NGOs' and 'Chambers' do not directly show any significance on process innovation for firms in Ankara. In contrast to the Ankara, 'Family' as informal linkages, 'Customers' and 'Intermediaries' as formal linkages and 'Chambers' as institutional linkages have a positively direct effect on process innovation in Konya. 'Family' and 'Customers', especially, is associated with process innovation in Konya due to interaction and socio-cultural characteristics of firms since the linkages can lead to coordination and control mechanisms for entrepreneurships that are developing as Turkish family firms, Indian home businesses, Japan Keiretsu, especially in the first phase of the organization and the growth process (Agapitova, 2003). The factors 'Family' and 'Customers', therefore, will lead to larger changes than 'Intermediaries' and 'Chambers' for the elasticity of the dependent variables in Konya firms (3.251 and 3.597 times versus 1.917 and 2.139 times). Therefore, the informal linkages can be considered as a starting point of the process innovative activities in the clusters to be fed by similar social and cultural background.

In addition to the explanatory variables, it can be seen that neither 'Experience', nor 'Skilled Labour' for firms in Ankara have an effect on process innovation. Similarly, 'Skilled Labour' for firms in Konya has no impact on process innovation. As affirmed by literatures, 'Size', 'Duration of Cooperation', 'R\&D' for firms in Ankara and Konya exhibit significant coefficients on process innovation. However, there is a striking finding that these variables in Ankara and 'R\&D' in Konya have a negative impact on the firm's process innovation. In others words, these variables have an effect to reduce process innovation for firms when analysed together with SNs. 'Size', for example, is likely to reduce in process innovation: 1.801 times $(1 / .555)$ in model 4, 1.323 times (1/.756) in model 5, 1.473 times (1/.679) in model 6 when increased one-unit in this variable. Concerning 'Duration of Cooperation' and 'R\&D', there are similar findings like the variable 'Size'. 


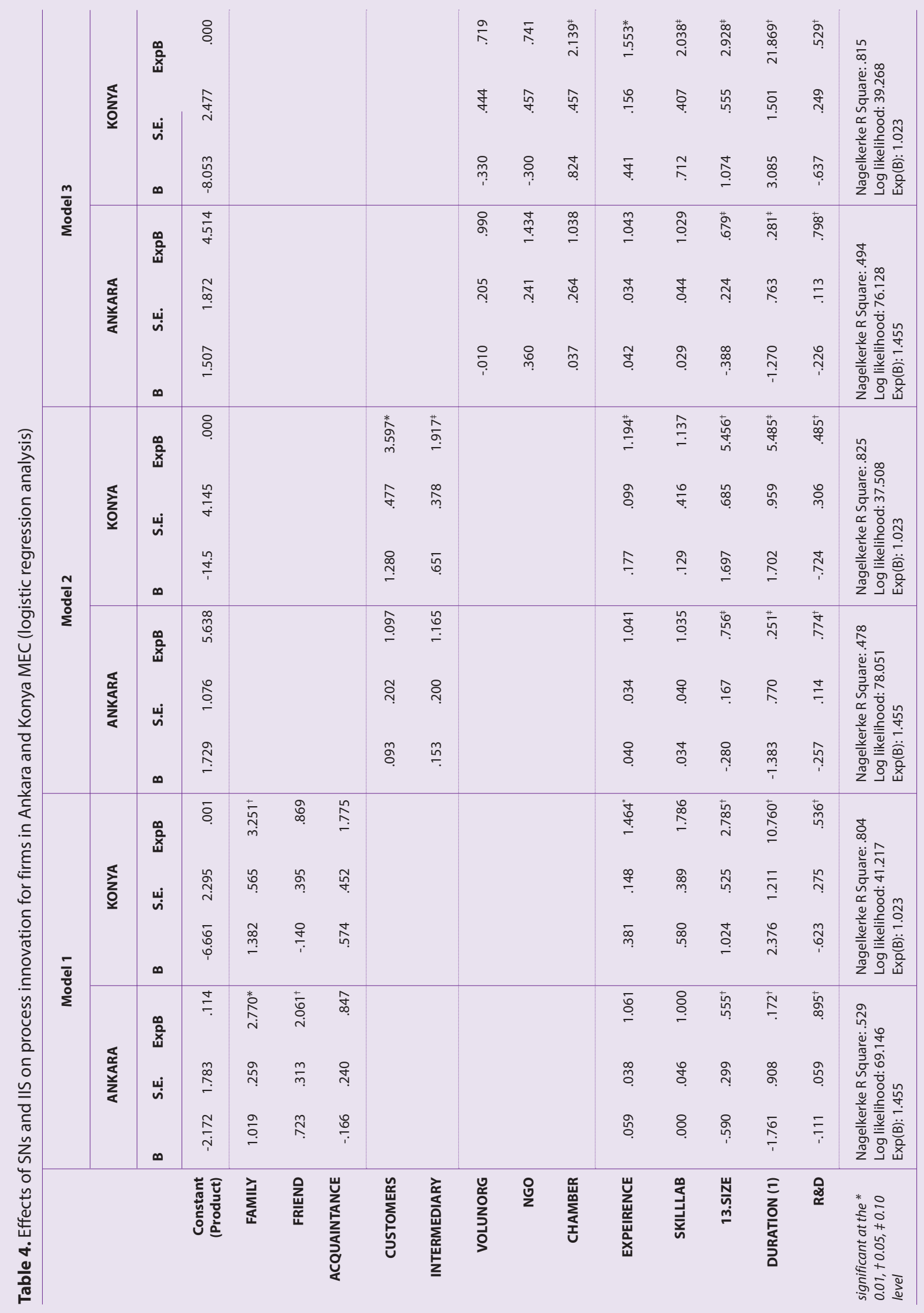




\section{Discussions}

The main point of the article explores whether SNs plays an important role in innovative activities. Information about the relationship between SNs and innovation of firms is presented in Figure 1 as product and process innovation in vertical axis and types of SNs in horizontal axis. As can be seen in Figure 1, for all firms, although the graphic by Likert values show SNs (informal, formal and institutional linkages) to impress as a major supporter of the innovation process like statistical analysis, the graphics can execute new findings arising from the relationship among the variables. As reported in Figure 1, informal linkages, expect product innovation in Ankara, are more dominant than formal and institutional linkages on both product and process innovation. The importance level of informal linkages, for example, is more than 'moderately important' for product and process innovation. As the evaluated results of statistical and graphical analysis, hypothesis 1 is confirmed for Ankara, and informal linkages in Konya are an important factor in product innovation, addition to process innovation.

This obtained finding in Konya case contradicts the literature since there are general supports that can cause a "lock-in" by informal linkages based on closed and repeated interactions among similar actors (Boschma \& Ter Wal, 2007; Grabher, 1993; Todtling \& Kaufmann, 2001). These findings may be explained by associating with restructuring issues of production process and social-cultural backgrounds of Konya. Firstly, the dominant family firms in district are a factor for the role of informal linkages on innovation versus formal and institutional linkages. Informal linkages are important channels to access new information and innovation of family firms to have self-taught entrepreneur and low-institutional structure (Karakayaci, 2013). It can also be the main reason of the importance of informal linkages due to use in manufacturing sectors of habits obtained by agricultural production in Konya. This is because transferring to manufacture industry of experience and knowledge gained by agricultural producing has led to sustaining the continuing of informal linkages existing in agricultural productions. Namely, informal linkages in Konya are usually the relations established among actors in agricultural productions before the manufacturing industry.

As emphasized in literature, informal linkages for Ankara firms, which have different characteristic features from Konya firms, generally have a decreasing effect on product innovation and an increasing effect on process innovation such as statistical findings. However, this graphics sates very definitely that informal linkages for Ankara firms alone are insufficient to make innovations a success, since, the important level of informal linkages, is between 'mod- erately important' and 'important' for product innovation, 'less important' and 'moderately important' for process innovation. Namely, there is no big range in the level of informal linkages. It, thus, can be said that control variables used in the statistical analysis have features triggering the effects on innovation of informal linkages for Ankara firms. Because the extent and the values to which informal linkages can contribute to firms' innovation may depend on quality and quantity of the control variables, referred to as firm characteristics or IIS (Cooke et al., 2005; Dahl \& Pedersen, 2004, 2005; Freel, 2000). The factors such as classmate, experience or working environments, mobility, thus, can lead to be an entity of informal linkages (Dahl \& Pedersen, 2004). Informal linkages, however, can inhibit the growth of new product and market because of information lock-in and imitations, although they contribute to each firm with technical advice, expectations, sharing of small ideas and opinions, as can be seen in Ankara firms.

Besides the role of informal linkages in innovation, the literature emphasizes that networks that are required for product and process innovation will be external linkages (formal and institutional) giving access to different information sources, for being absorbed by district firms of tacit and coded information (Boschma \& Ter Wal, 2007; Dahl \& Pedersen, 2005; Erkus-Ozturk, 2008; Freel, 2000; Granovetter, 1973). Castilla et al. (2000), for example, discussed whether actors such as voluntary organizations, chambers, NGOs, and commercial agents contribute to firms with learning and technological development. Hashi and Stojcic (2010) emphasized attention on the importance of environmental factors such as markets, competitors, universities and institutions in innovation. Kemp, Folkeringa, De Jong, and Wubben (2003) stated that cooperation with R\&D institutions could positively affect innovative activities. Lööf and Heshmati (2006) stated that increasing the intensity of cooperation with competitors and some external resources have a positive effect on innovative activities. Allen and Cohen (1969) have emphasized that firms, which have strong SNs, can provide continuity through taking information from the outside of a region, if firms do not have the chance to establish an $R \& D$. The result of the research for district firms show that formal and institutional linkages have a critical importance to be adapted into innovation process by eliminating risk and uncertainty as a result of bringing access to tacit and coded information from outside the region. Thus, the second hypothesis is confirmed for both of the district firms.

As mentioned at the statistical findings, 'Customers' and 'Intermediaries' are the most important linkages for Konya firms' product innovation. These linkages for Konya firms due to production structure of agriculture machinery manufacturing being dominant sector in Konya MEC are a 
guide to contribute to the development and improvement of product and technical skills with suggestions, ideas, advice and feedback by users. 'Intermediaries' in Konya not only perform the issues that need to be carried out by which firms have limited to access to customers and suppliers, but also play a role in providing full support studies with suggestions and ideas submitted. However, as found in the statistical analysis, 'Customers', are more important than 'Intermediaries' for product innovation in Ankara due to production style of this cluster. Since the firms in Ankara are more institutional, and prefer a direct relation with their supplier and customers for product innovation. On the other hand, as can be seen in Figure 2, formal linkages in Ankara did not reflect a significant change for in the level of innovation: from low process innovation to high process innovation like statistical findings. However, it can be said that control variables trigger the effect on innovation of formal linkages, as mentioned by interviewers below.

"We connect directly to our customers, suppliers and other cooperation firms and institutions. We think this is the most effective solution for problem solving and new ideas..... (in-depth interviews with firms in Ankara)"

"....... we think intermediaries are a unit of our firm. They provide us with both ideas from customers and new information from suppliers.......(in-depth interviews with firms in Konya)"

In addition, this article argues that we should determine the relationship between institutions and innovation since formal linkages only consist of the interactions with customers and intermediaries intended for development production and marketing issues, whereas
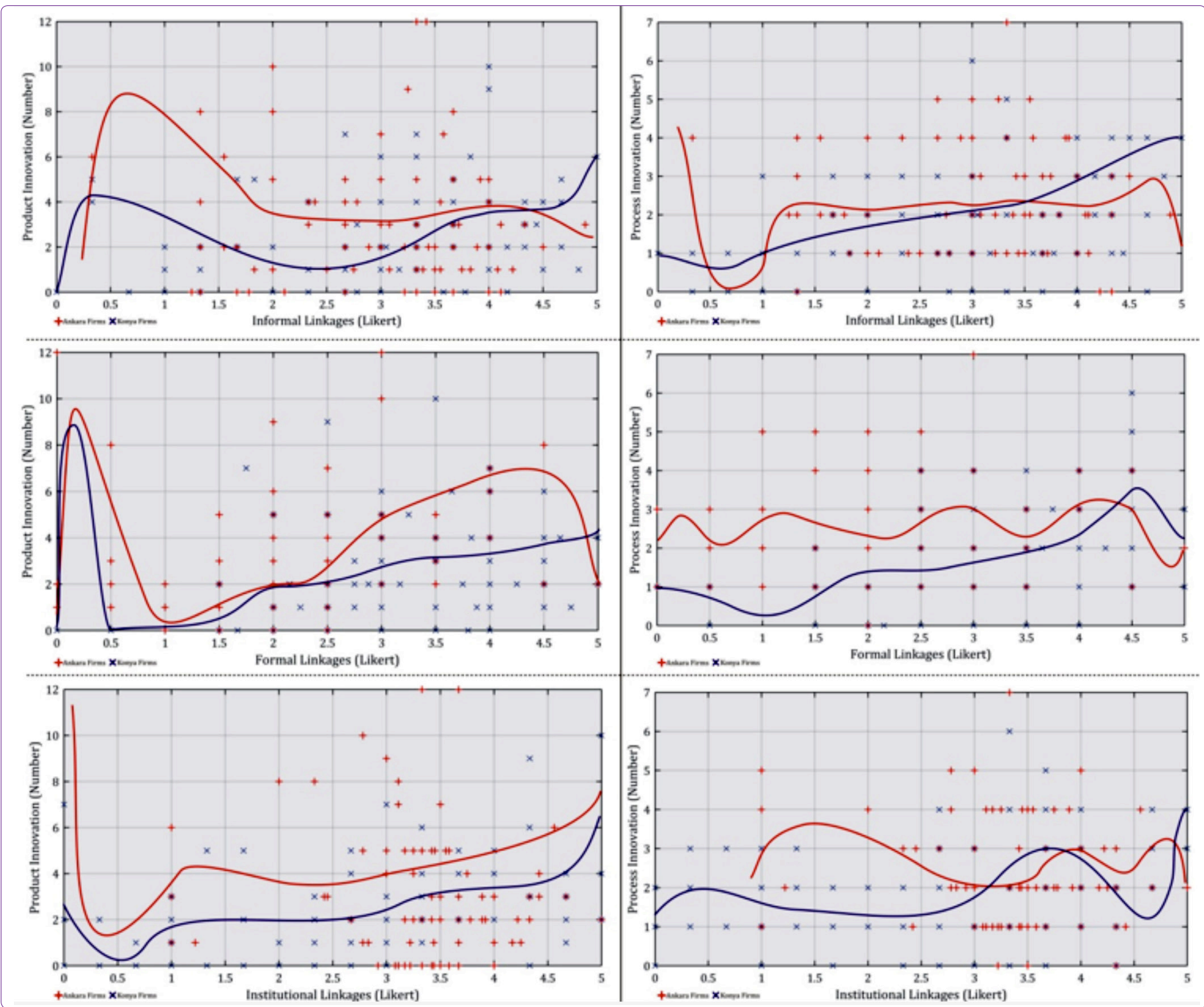

Figure 2. The relationship between product/process innovation and SNs in Ankara and Konya industrial clusters. 
institutional linkages are the key factors for improving environmental conditions in learning and innovation processes (Molina-Morales \& Martínez Fernández, 2010). As separate from formal linkages, therefore, we viewed institutional linkages referring to the values and qualities of untraded specific sources in the local environment. These linkages can improve learning process of firms in several ways such as technological and managerial skills services, training activities, interactions with different actors for solutions to problems etc. (Molina-Morales, LópezNavarro, \& Guia-Julve, 2002; Molina-Morales \& Martínez Fernández, 2010). Indeed, the results of the analyses confirmed that the institutional linkages aiming to get new information and ideas through interactions with actors in local environment have great significance than informal linkages and even formal linkages for product innovation activities of firms (Table 3). Especially in product innovation for both district firms, innovative firms think that institutional linkages should have a significant level above 'moderately important' in product innovation activities. It is also stated that the both district firms do not need institutional linkages in process innovation, when ignored the effects of 'Chambers' on process innovative firms in Konya. As can be seen in Figure 2, the significant level of institutional linkages cannot be indicated movement from 'moderately important' for process innovative firms in Ankara. This take place a change from 'less important' to 'moderately important' for process innovative firms in Konya because of the effect of 'Chambers' on process innovation. Namely, the product innovative firms in all districts should take part in interactions with various institutions in training activities, fairs and support services in order to the develop new product and manufacturing technologies. The evidence becomes further remarkable when these firms are not willing to act involved in improving of manufacturing technologies and process with institutional linkages, if they are excluded from the 'Chambers' in Konya. The main reason is that the primary function of 'Chambers' in Konya is to maintain and improve politics and lobby power of the firms in local milieu, rather than developing their capability for innovation with overseas institutional linkages. Thus, 'Chambers' in Konya has the role as a sample of informal linkages to get involved in process innovation since it consists of the firms having similar political, religious, cultural, and social backgrounds.

"Institutions can offer amenities such as prepared accommodation and an interpreter for a firm manager.................. to participate in the fair overseas ........... to find new markets in the process of overseas visits. They can also provide cooperation with firm managers who come from different countries...... (in-depth interviews with firms in Ankara and Konya)" "we can find many chambers about manufacturing and service sector in the region. However, the chambers aim to be the ascendant with firms from the same politic thoughts......(in-depth interviews with firms in Konya)"

As emphasized in methodology, the literature points out that control variables have a role in triggering innovation process with tacit and coded knowledge acquired by SNs due to being associated with individual innovation capability in firm. Namely, the capacity of a firm' information creation makes connection to SNs more valuable (ErkusOzturk, 2008; Koschatzky, 2000). In addition to statistical analysis, this part examined the extent to which SNs are more effective with the control variables in innovation process, considering graphical and in-depth analyses (Figure 3). These findings substantially confirm the third hypothesis, although human capital of the district firms has big disparities to contribute to the effects on innovative activities of SNs. As stated the statistical analysis and Figure 3, along with graphical and in-depth analyses demonstrate that the control variables have different effects on product and process innovation.

Accordingly, it can be said that 'Experience' is to be of little effect on innovation in all firms, although there is no absolute accuracy between 'Experience' and product/ process innovation in the analyses. As seen in $++^{2}$ area of Figure 3, most of the firms have less than 10 years of experiance in all districts and it is noted that although almost half of the firms with less than 10 years of experience are located in Ankara have at least one product innovation activity, the other half of the firms do not have any product innovation activity. This evidence is also acceptable for firms with more than 10 years' experience, since they contain firms with both non-innovation and innovation. This uncertainty is more descent in Konya for product innovation. However, as seen in -+ and +- areas of Figure 3, the firms with less than 10 years of experience in Ankara can be the effect of increasing on product innovation due to having at high level of SNs. In other words, new firms have the ability to be more adaptable to social network with high human capital potentials. This provide a higher potential to reach new information (Bas, Amoros, \& Kunc, 2008; Yli-Renko, Autio, \& Sapienza, 2001) with higher competitive and labour mobility provided by SNs. 'Experience' for Konya firms has deprived from the effects triggering product innovation since it has not drived from force forming SNs for product innovation due to institutional structure and traditional production style of the district firms characterized by dominant family firms, spin-off growth, imitation etc.. In other words, reputation and awareness

This was defined by areas between axes while referring to figure 3 . For example, the ++ areas is reference for district being positive in $\mathrm{x}$ and $\mathrm{y}$ axes, -+ areas for district being negative in $\mathrm{x}$ axis and positive in $\mathrm{y}$ axis, +- areas for district being positive in $\mathrm{x}$ axis and negative in $\mathrm{y}$ axis. 


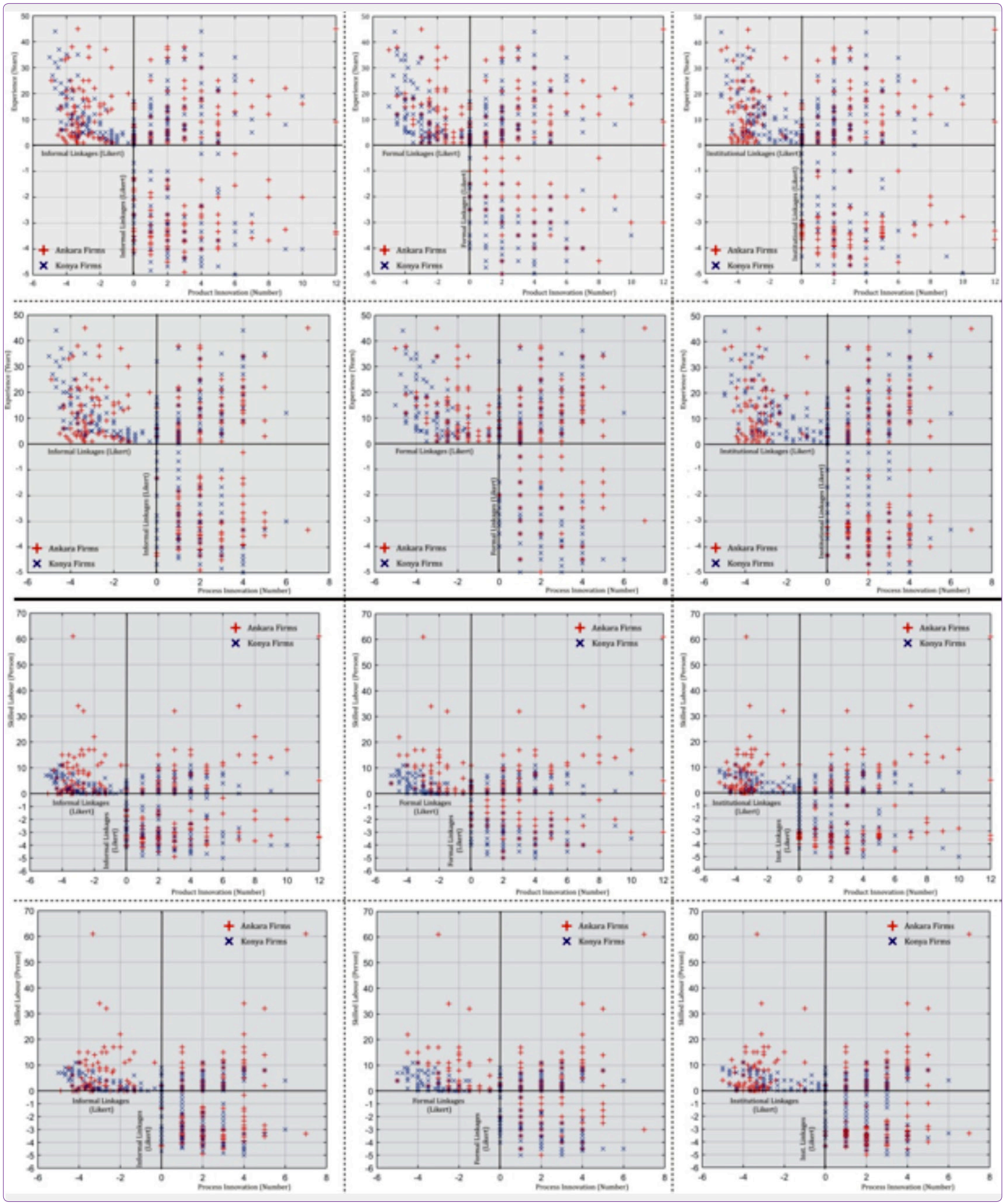

Figure 3. The relationships between innovation, SNs and IIS. 

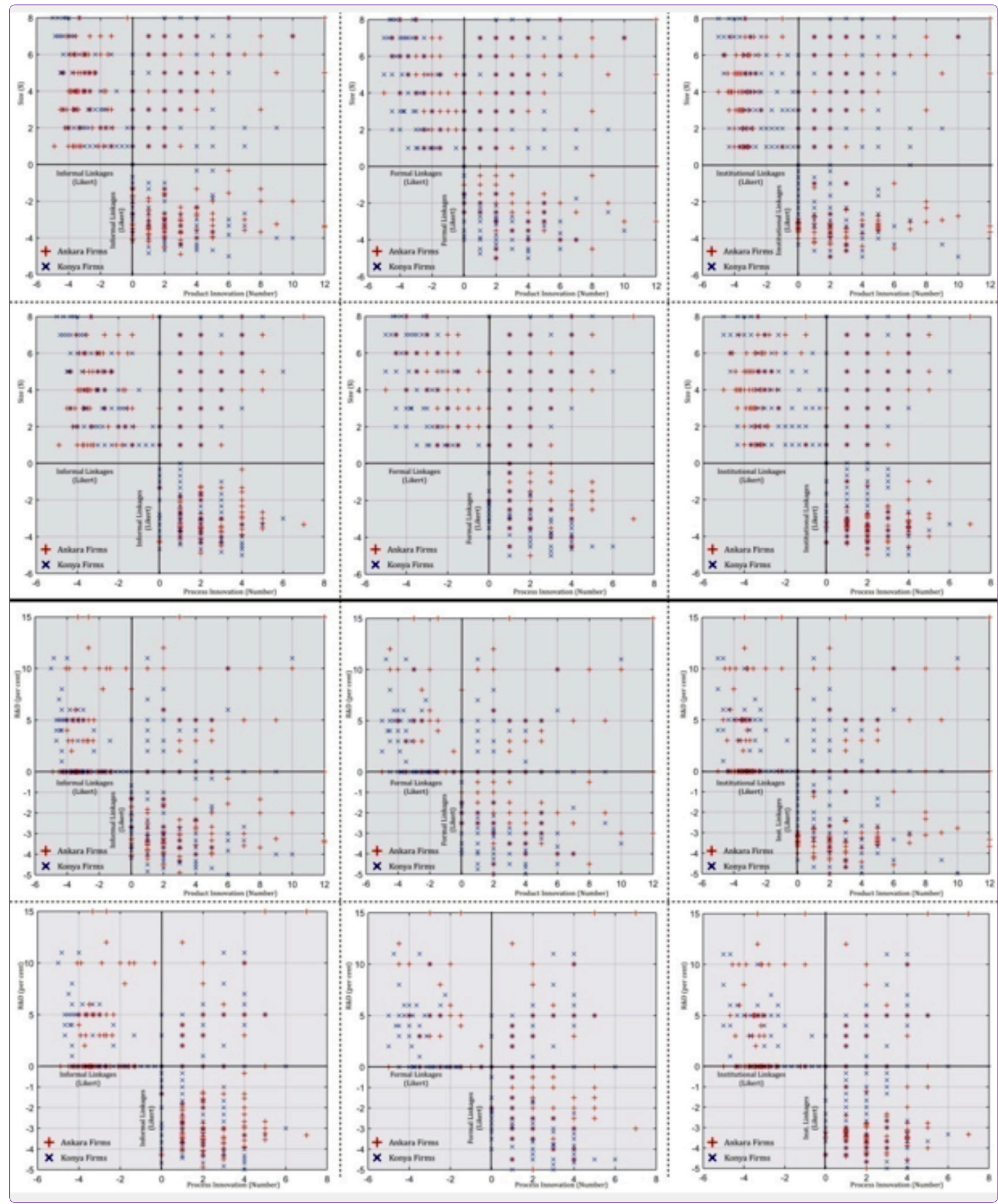

Figure 3. The relationships between innovation, SNs and IIS (continuation). 
as the output of experiences do not play a role in the development of SNs for innovative activities since SNs in Konya are provided by closed relations and political affiliations, instead of the firms' recognition in local milieu. This debate, though expressed on positive relations in statistical analysis for Konya firms, can appear in a more dominant process innovation in the in-depth and graphical analysis for all firms. Hence, it can be said that the effects on innovation of 'Experience', as expressed in the graphical and in-depth analysis, are not consistent with the result in the literature since it alone does not cause sustainable reputation and awareness to be important for innovative activities.

Moreover, in Figure 3 and in-depth analysis, 'Skilled Labour' has a meaningless effect on product and process innovation for all firms, which is unlike the findings of statistical analysis. In fact, this finding is very similar to the literature since skilled labour has the skills to manage learning and knowledge process for problem solving (Dahl \& Pedersen, 2005; Granovetter, 1973). They are the most interactive employees of clusters with the role of having all stages in manufacturing from design to production, from setting up of the supplier chain to marketing and from institutional organizations to personal relations. As can be seen in the Figure 2, this cannot be stated as to having a lasting effect on what makes it continuously innovative for skilled labour, for missing the formation of SNs in all districts. In other words, the significant level of SNs is not based on the number of skilled labour. This indicates express diversity in the meaning of 'Skilled Labour' for all firms. However, this graph indicates that 'Skilled Labour' may only allow the establishment of relations in especially formal and institutional level for product innovation of Ankara firms. As admitted by many firms, there are the employees that perform certain stages of the production organization, not managing the organization, whereas it is a strategy for the success of many firms giving responsibility to employees in all production organization. This strategy is the main source of the emergence of trust which improves SNs and decline high uncertainty-risk for learning and innovation, as mentioned above.

"...works like a closed circuit system of the production process in terms of responsible of personal due to the hesitation to be the duplication of production information. Engineers, thus, do not include within the production organization by firms' owner or managers. There is an understanding to make a joint of the firm to engineer if he is indispensable for firms with the contribution....(in-depth interviews with firms in Ankara and Konya)"

As expressed in the literature, 'Size', 'Duration of Cooperation' and 'R\&D' are important for both the value increase of SNs and association with product and process innovation for all firms (Burt, 2004; Cohen \& Klepper, 1996; Cooke et al., 2005; Molina-Morales \& Martínez Fernández, 2010). These findings are confirmed by graphical and indepth analyses along with the results of statistical analysis. In fact, it shows that variables not only provide the survival by absorbing the information for the firms, but also develop the potentials to be competitive the by making effective of SNs on innovation.

Table 5. Innovative status for firms by duration of collaboration

\begin{tabular}{|c|c|c|c|c|c|c|c|c|c|}
\hline \multirow[t]{3}{*}{ Duration of Cooperation } & \multirow[t]{3}{*}{ Innovative Status } & \multicolumn{4}{|c|}{ Product Innovation } & \multicolumn{4}{|c|}{ Process Innovation } \\
\hline & & \multicolumn{2}{|c|}{ Ankara } & \multicolumn{2}{|c|}{ Konya } & \multicolumn{2}{|c|}{ Ankara } & \multicolumn{2}{|c|}{ Konya } \\
\hline & & $\mathbf{n}$ & $\%$ & $\mathbf{n}$ & $\%$ & $\mathbf{n}$ & $\%$ & $\mathbf{n}$ & $\%$ \\
\hline \multirow[t]{7}{*}{ Long-Term Relations } & The firms having not any & & & & & & & & \\
\hline & innovative activities & 0 & 0.0 & 7 & 7.9 & 0 & 0.0 & 6 & 6.7 \\
\hline & The firms having one or two & & & & & & & & \\
\hline & innovative activities & 35 & 43.2 & 34 & 38.2 & 39 & 48.1 & 42 & 47.2 \\
\hline & The firms having three or more & & & & & & & & \\
\hline & innovative activities & 19 & 23.5 & 16 & 18.0 & 15 & 18.5 & 11 & 12.4 \\
\hline & Total & 54 & 66.7 & 57 & 64.0 & 54 & 66.7 & 57 & 64.0 \\
\hline \multirow[t]{7}{*}{ Short-Term Relations } & firms not having not any & & & & & & & & \\
\hline & innovative activities & 13 & 16.0 & 13 & 14.6 & 10 & 11.2 & 15 & 16.9 \\
\hline & firms having one or two & & & & & & & & \\
\hline & innovative activities & 6 & 7.4 & 12 & 13.5 & 11 & 12.4 & 14 & 15.7 \\
\hline & firms having three or more & & & & & & & & \\
\hline & innovative activities & 8 & 9.9 & 7 & 7.9 & 6 & 6.7 & 3 & 3.4 \\
\hline & Total & 27 & 33.3 & 32 & 36.0 & 27 & 33.3 & 32 & 36.0 \\
\hline
\end{tabular}


The literature explains the role of 'Size' within the effects of SNs on innovation with growing market conditions (Cooke et al., 2005; Dahl \& Pedersen, 2004, 2005; Stephan, 2011). Since, 'Size' is directly associated with market, it may offer dynamic SNs for new information acquiring from a variety of resources instead of closing and repeating interactions leading to lock-in of innovation process. For this reason, 'Size' is a factor that will increase the number of connections with different firms or institutions providing innovation process. Thus, it can be said that they continuously try to find new connections for the success of firms, besides existing connections. Also they prefer using longterm relations rather than short-term in all districts too, as emphasized in Table 5. This means that 'Size' and 'Duration of Cooperation' are not the only sources deriving the potentials within firms for information and learning, but they also promote interactive and path-dependence learning process. This aims to improve the firms competitive conditions, which can be done by making an effective innovation on SNs. At this point, it is important to note that firms can be innovative in the condition that they have R\&D capabilities being able to convert new product with diffusing knowledge and information through SNs. Hence, this process can only ensure remarkable continuity of cooperation (Malecki \& Tootle, 1996; Molina-Morales \& Martínez Fernández, 2010).

As reported in Figure 3, as the R\&D expenditures increase, firms have the more product innovative activities and process innovation put aside in time. There is an interesting finding to emerge from the graphical, although this finding is consistent with the result of statistical analysis. This presents a significant amount of the firms, which are not carrying out R\&D expenditure, with the aim of attempting to grow product and process innovation with knowledge from various sources through SNs. However, as mentioned above, when trust is deprived, this leads to a weakening of the competitiveness of the regions, with imitation, low-quality production, price stability and poor reputation of the regions in the sight of other regional firms and institutions. This threat is more predominant in Konya, as expressed in the in-depth interview, since Konya is devoid of mentality and the potential technological diversity and infrastructure, institutional prosperity, knowledge milieu, focal and bridging firms or actors, which will eliminate all the minus factors in the production process.

Considering that long-term relationships contribute to the development of trust (lyer, Kitson, \& Toh, 2005; Ruuskanen, 2004; Yli-Renko et al., 2001) and trust is the value indicator being the cohesion of SNs and getting tacit and coded knowledge for innovation (Fukuyama, 1995; Murphy, 2002), this analyses confirms that 'Duration of Coop- eration' is an important variable for innovation and SNs, as found in the statistical analysis. Indeed, Table 5 shows that two-third of all firms prefer long term-relations and all the firms in Ankara and 90 per cent in Konya are innovative firms for product and process innovation. However, short-term relations make up only half of all firms. This can be explained by the fact that long-term relations for a firm provide benefits such as maintaining supply chain and exchanging knowledge, sharing market and technological, supporting financial, as expressed in the in-depth interviews. The firms with short-term relations are cautious about innovation and exchanging knowledge due to not only high risk and imitation in production process, but also low-quality production that derives plenty of slack in longterm cooperation. However, they may carry out more useful SNs for innovative processes, with the firms' capabilities defeating these issues. As observed in the field study, these firms have the role of the bridge by offering external knowledge and institutions for district firms and forming knowledge networks within the district.

"You can have networks and cooperation with many actor/firm/institutions to develop competitive and innovative structure if you can fill a gap in the market. Otherwise, the relationship lose that efficiency because of repeated interactions...... (in-depth interviews with firms in Ankara and Konya)"

Firms hope to be carried out certain stages of $R \& D$ by district institutions for reducing $R \& D$ cost and expenditure....(in-depth interviews with firms in Konya)"

"....... whether duration of cooperation will be short or long time in a project depends on the level of trust occurring cooperation process. In the condition that the cooperation is not based on trust, the different factor may become a part of an activity or effort such as power relations, dependency or necessity for long-term...(in-depth interviews with firms in Konya)"

\section{Conclusion}

The article described whether SNs were required for innovation and the firm's evolution, with statistical and in-depth interview research methods in the Turkish case. The overall conclusions of this article showed that the hypotheses are substantially confirmed by the analyses in the case of Ankara and Konya.

This means that firstly the importance of SN types in the cases refer to the required action that is necessary for the effects on types of innovative activities. In other words, they can contribute to innovative activities as long as the $\mathrm{SN}$ types have the ability to access different knowledge sources, as mentioned in the literature. This article proves that types of SNs differ from insights within the framework of the degree and types of innovation, considering 
the structure of interactions and background and behaviours of the clusters. Indeed, this article shows that informal linkages can assume the role for increasing product innovation like formal and institutional linkages. Informal channel may be critical to acquire tacit and coded knowledge, as mentioned in the role on manufacturing industry informal relations obtained by agricultural sector in Konya. The real effects of informal linkages, however, are to improve on the process innovation since production information and technologic habits belong to a particular region. In other words, the characteristics and historic background of the clusters can play a role to form the social network that has an influence on learning process. Moreover, this reveals that the social network typologies that are stated in the literature can show an alteration according to the features and historic background of the case clusters. For example, it is seen that local embeddedness in Konya mechanical engineering clusters led to prevent the radical and constant changes.

As emphasized in the literature, we found that formal and institutional linkages are valuable interactions established by district firms for product innovative activities. Formal and institutional linkages are the main source of interactions with actors offering technical skills with suggestions, ideas, advice and feedback by users. These linkages, thus, are necessary relations for the learning process of district firms. While considering compulsory or voluntary relations in informal linkages because of supporting and watching of acquaintances and relatives enjoined by traditional way of thinking. This prevents firms developing innovative activities because of not offering diversity of information for competition and marketing conditions despite providing the benefits for firms' survival in critical point such as economic crisis. However, this article evidence that SNs generally are not only important factors to increase the innovation process, but also a 'starting point' for firms due to enriching the learning process and knowledge resources.

In addition, this article has shown that IIS are more important in the effects exposed in order to enable SNs allowing the continuity of innovation being a path-dependent process. As mentioned in the literature (Burt, 2004; Coleman, 1998; Woolcock, 2001), IIS associated with human capital, generally has a similar role in innovation for district firms. However, they not only have the ability to convert the roles of SNs on innovation according to institutional and social structure, production styles etc. of the districts in local environment, but also guide the firms to interact with related actors.

Also, we aimed to draw attention to the weakness of the positivist analysis done on abstract concepts such as SNs, with a comparison of statistical, graphical and in-depth interview analyses. Statistical analyses proved that the role on firms' success of SNs should not be insufficiently explained since they can be completely inadequate to explain the role of indirect social relations. Indirect linkages, which cannot be defined by survey data used for statistical analysis, are more important than direct linkages for innovative activities of firms (Molina-Morales \& MartínezFernández, 2010). Indeed, the facts behind the results of the statistical analyses have gained more meaning with findings obtained by in-depth interviews and informal channels such as conversations about general issues after interviews, observations in the manufacturing areas and talking with employees in socio-cultural areas.

Lastly, the typologies of industrial clusters and cluster environment are effective factors in the formation of social networks. Hence, the effects of social networks on innovation differ from cluster to cluster. Therefore, in these studies the characteristic of cluster should be well analysed in order to avoid methodological errors. In this study, it was seen that the social network typologies of the innovation activities could differentiate in clusters having different characteristics. For example, the institutions such as chambers were working as informal linkages in the machine manufacture cluster in Konya, and young entrepreneurs have adopted the competitive firm strategies, although they have little experience in Ankara.

\section{References}

Agapitova, N. (2003). "The impact of social networks on innovation and industrial development: Social dimensions of industrial dynamics in Russia", Paper presented at the Creating, Sharing and Transferring Knowledge, the Role of Geographical Configurations, Institutional Settings and Organizational Contexts, Copenhagen.

Allen, T. J., and Cohen, S. I. (1969). "Information flow in research and development laboratories". Administrative Science Quarterly, 14(1), pp. 12-19.

Aloysius Gunadi, B. (2011). "Social networks and innovation (Handicraft Industry in Bantul, Yogyakarta)". Munich Personal Repec Archive Paper No: 28032, Munich.

Amin, A., and Thrift, N. (1994). "Living in the global", In A. Amin \& N. Thrift (Eds.), Globalization, Institutions and Regional Development in Europe, 1st ed. New York: Oxford University Press, pp. 1-22.

Armatli-Koroglu, B. (2005). "Innovativeness in industrial districts of Turkey and indicators of innovation activities in SMEs". Gazi University Journal of Science, 18(4), pp. 693-706.

Autio, E., Sapienza, H. J., and Almeida, J. G. (2000). "Effects of age at entry, knowledge intensity, and imitability on international growth". Academy of Management Journal, 43(5), pp. 909-924.

Bas, T. G., Amoros, E., and Kunc, M. (2008). "Innovation, entrepreneurship and clusters in Latin America natural resource: implication and future challenges". Journal of Technology Management \& Innovation, 3(4), pp. 52-65.

Boschma, R. A., and Ter Wal, A. L. (2007). "Knowledge networks 
and innovative performance in an industrial district: the case of a footwear district in the South of Italy". Industry and Innovation, 14(2), pp. 177-199.

Burt, R. S. (2004). "Structural holes and good ideas". American Journal of Sociology, 110(2), pp. 349-399.

Castilla, E. J., Hwang, H., Granovetter, E., and Granovetter, M. (2000). "Social networks in silicon valley". In C. Lee, W. Miller, M. Hancock, \& H. Rowen (Eds.), The Silicon Valley Edge, 1st ed. Stanford: Stanford University Press, pp. 218-247.

Chen, M. C. (2002). Industrial district and social capital in Taiwan's economic development: An economic sociological study on Taiwan's bicycle industry. Unpublished Ph.D., Yale University,

Cohen, W. M., and Klepper, S. (1996). "A reprise of size and R\&D”. The Economic Journal, 106(437), p. 925.

Coleman, J. S. (1998). "Social capital in the creation of human capital". American Journal of Sociology, 94(1), pp. 95-121.

Cooke, P., Clifton, N., and Oleaga, M. (2005). "Social capital, firm embeddedness and regional development". Regional Studies, 39(8), pp. 1065-1077.

Dahl, M. S., and Pedersen, C. (2004). "Knowledge flows through informal contacts in industrial clusters: myth or reality?". Research Policy, 33(10), pp. 1673-1686.

Dahl, M. S., and Pedersen, C. (2005). "Social networks in the $R \& D$ process: the case of the wireless communication industry around Aalborg, Denmark". Journal of Engineering and Technology Management, 22(1-2), pp. 75-92.

Dicken, P., and Malmberg, A. (2001). "Firms in territories: A relational perspective". Economic Geography, 77(4), pp. 345-363.

Eraydin, A., and Armatli-Koroglu, B. (2005). "Innovation, networking and the new industrial clusters: the characteristics of networks and local innovation capabilities in the Turkish industrial clusters". Entrepreneurship \& Regional Development, 17(4), pp. 237-266.

Erkus-Ozturk, H. (2008). The role of local and global networking for tourism firms and clusters: The case of Antalya. (Unpublished PhD Thesis), Ankara.

Field, J. (2003). Social capital. London: Routledge.

Freel, M. (2000). "External linkages and product innovation in small manufacturing firms". Entrepreneurship \& Regional Development, 12(3), pp. 245-266.

Fukuyama, F. (1995). Trust. New York: Free Press.

Gertler, M. (1997). "The invention of regional culture". In J. Wills and R. Lee (Eds.), Geographies of Economies,1st ed. London: Edward Arnold, pp. 47-58.

Gordon, I. R., and McCann, P. (2000). "Industrial clusters: complexes, agglomeration and/or social networks?". Urban Studies, 37(3), pp. 513-532.

Grabher, G. (1993). "Rediscovering the social in the economics of interfirm relations". In G. Grabber (Ed.), The Embedded Firm: On the Socioeconomics of Industrial Networks, 1st ed. London: Routledge, pp. 1-32.

Granovetter, M. S. (1973). "The strength of weak ties". American Journal of Sociology, 78(6), pp. 1360-1380.

Greene, P. G., and Brown, T. E. (1997). "Resource needs and the dynamic capitalism typology." Journal of Business Venturing, 12(3), pp. 161-173.

Hashi, I., and Stojcic, N. (2010). "The impact of innovation activi- ties on firm performance using a multi-stage model: Evidence from the community innovation". Warsaw-Poland: CASECenter for Social and Economic Research (online access date: 14.01.2011 and http://case.research.eu).

Hauser, C., Tappeiner, G., and Walde, J. (2007). "The learning region: the impact of social capital and weak ties on innovation". Regional Studies, 41(1), pp. 75-88.

Iyer, S., Kitson, M., and Toh, B. (2005). "Social capital, economic growth and regional development". Regional Studies, 39(8), pp. 1015-1040.

Johansson, B., and Lööf, H. (2008). "Innovation activities explained by firm attributes and location". Economies of Innovation and New Technonology, 17(6), pp. 533-552.

Karakayaci, O. (2013). "Social capital and innovation in industrial clusters: an evidence from case of family and non-family firms in Turkey". European Online Journal of Natural and Social Sciences, 2(3), pp. 313-329.

Karlsson, C. (1997). "Product development, innovation networks, infrastructure and agglomeration economies". The Annals of Regional Science, 31(3), pp. 235-258.

Kemp, R. G., Folkeringa, M., De Jong, J. P., and Wubben, E. F. (2003). "Innovation and firm performance". EIM Business and Policy Research Scales Research Reports, No: H200207.

Knack, S., and Keefer, P. (1997). "Does social capital have an economic payoff? A cross-country investigation". The Quarterly Journal of Economics, 112(4), pp. 1251-1288.

Kogut, B., and Zander, U. (1992). "Knowledge of the firm, combinative capabilities, and the replication of technology". Organization Science, 3(3), pp. 383-397.

Koschatzky, K. (2000). "A river is a river-cross-border networking between Baden and Alsace". European Planning Studies, 8(4), pp. 429-449.

Landry, R., Amara, N., and Lamari, M. (2002). "Does social capital determine innovation? To what extent?". Technological Forecasting and Social Change, 69(7), pp. 681-701.

Lin, N. (2001). Social capital. Cambridge: Cambridge University Press.

Lissoni, F. (2001). "Knowledge codification and the geography of innovation: The case of Brescia mechanical cluster". Research Policy, 30(9), pp. 1479-1500.

Lööf, H., and Heshmati, A. (2006). "On the relationship between innovation and performance: A sensitivity analysis". Economics of Innovation and New Technology, 15(4-5), pp. 317344.

Malecki, E. J., and Tootle, D. M. (1996). "The role of networks in small firm competitiveness". International Journal of Technology Management, 11(1-2), pp. 43-57.

Martin, R., and Sunley, P. (2001). 'Rethinking the 'Economic' in economic geography: Broadening our vision or losing our focus?". Antipode, 33(2), pp. 148-161.

Maskell, P., and Malmberg, A. (1999). "Localised learning and industrial competitiveness". Cambridge Journal of Economics, 23(2), pp. 167-185.

Molina-Morales, F. X., López-Navarro, M. Ã., and Guia-Julve, J. (2002). "The role of local institutions as intermediary agents in the industrial district". European Urban and Regional Studies, 9(4), pp. 315-329.

Molina-Morales, F. X., and Martínez-Fernández, M. T. (2010). 
"Social networks: effects of social capital on firm innovation". Journal of Small Business Management, 48(2), pp. 258-279.

Morgan, K. (1997). "The learning region: institutions, innovation and regional renewal". Regional Studies, 31(5), pp. 491-503.

Murphy, J. T. (2002). "Networks, trust, and innovation in Tanzania's manufacturing sector". World Development, 30(4), pp. 591-619.

Romijn, H., and Albaladejo, M. (2002). "Determinants of innovation capability in small electronics and software firms in southeast England". Research Policy, 31(7), pp. 1053-1067.

Ruuskanen, P. (2004). "Social capital and innovation in small and medium sized enterprises". DRUID Summer Conference 2004: Industrial Dynamics, Innovation and Development, Elsinore.

Sabatini, F. (2009). "Social capital as social networks: A new framework for measurement and an empirical analysis of its determinants and consequences". The Journal of Socio-Economics, 38(3), pp. 429-442.

Saxenian, A. (1994). Regional advantage. Cambridge, Mass.: Harvard University Press.

Staber, U. (2001). "Spatial proximity and firm survival in a declining industrial district: The case of knitwear firms in BadenWurttemberg". Regional Studies, 35(4), pp. 329-341.

Staber, U. (2007). "Contextualizing research on social capital in regional clusters". International Journal of Urban and Regional Research, 31(3), pp. 505-521.
Stephan, A. (2011). "Locational conditions and firm performance: introduction to the special issue". The Annals of Regional Science, 46(3), pp. 487-494.

Storper, M. (1999). "The resurgence of regional economies, ten years later: the region as a nexus of untraded interdependencies". In J. Bryson, N. Henry, D. Keeble, \& R. Martin (Eds.), The Economic Geography Reader, New York: John Wiley and Sons, pp. 209-215.

Sverrisson, A. (1994). "Making sense of chaos: Socio-technical networks, careers and entrepreneurs". Acta Sociologica, 37(4), pp.401-417.

Todtling, F., and Kaufmann, A. (2001). "The role of the region for innovation activities of SMEs". European Urban and Regional Studies, 8(3), pp. 203-215.

Uzzi, B. (1997). "Social structure and competition in interfirm networks: The paradox of embeddedness". Administrative Science Quarterly, 42(1), pp. 35-67.

Woolcock, M. (2001). "The place of social capital in understanding social and economic outcomes". Canada: International Symposium Report on Human Resources Development: pp.65-88 (online access date: 13.04.2014 and http://www. oecd.org/innovation/research/1824913.pdf).

Yli-Renko, H., Autio, E., and Sapienza, H. J. (2001). "Social capital, knowledge acquisition, and knowledge exploitation in young technology-based firms". Strategic Management Journal, 22(6-7), pp. 587-613. 